\title{
First description of the male of Oonops nigromaculatus Mello-Leitão, 1944 (Araneae: Oonopidae) with the redescription of the female and new records
}

\author{
Cristian J. GRISMADO ${ }^{1}$, Gilberto ÁVALOS² \& Alda GONZÁLEZ ${ }^{3}$
}

\begin{abstract}
1División Aracnología, Museo Argentino de Ciencias Naturales «Bernardino Rivadavia» Av. Angel Gallardo 470, C1405DJR, Buenos Aires, Argentina; grismado@macn.gov.ar. ${ }^{2}$ Cátedra Biología de los Artrópodos, Facultad de Ciencias Exactas y Naturales y Agrimensura, Universidad Nacional del Nordeste, Av. Libertad 5470, W3404AAS, Corrientes, Argentina; gilbertoa@exa.unne.edu.ar. ${ }^{3}$ CEPAVE (CCT-CONICET La Plata), Universidad Nacional de La Plata. Calle 2 N$^{\circ} 584$, B1900CHX, La Plata, Buenos Aires, Argentina; asgonzalez@cepave.edu.ar
\end{abstract}

\begin{abstract}
The male of Oonops nigromaculatus Mello-Leitão 1944 is described for the first time and the female is redescribed from recently collected specimens. New records from Argentina and Uruguay are provided.

Key words: Araneae, Haplogynae, Dysderoidea, Oonopidae, Argentina, Uruguay.

Resumen: Primera descripción del macho de Oonops nigromaculatus Mello-Leitão, 1944 (Araneae: Oonopidae) con la redescripción de la hembra y nuevos registros. Se describe por primera vez el macho de Oonops nigromaculatus Mello-Leitão 1944, y la hembra se redescribe sobre la base de nuevos especímenes colectados recientemente. Se proveen nuevos registros de la Argentina y Uruguay.
\end{abstract}

Palabras clave: Araneae, Haplogynae, Dysderoidea, Oonopidae, Argentina, Uruguay.

\section{INTRODUCTION}

The Oonopidae is a family of small to very small haplogyne, ecribellate, six-eyed spiders whose greatest diversity occurs in tropical regions (Jocqué \& Dippenaar-Schoeman, 2006). They comprise around 507 described species in 73 genera (Platnick, 2009), although there is evidence that these numbers represent only a small fraction of current oonopid diversity (Fannes \& Jocqué, 2008). Simon (1890) established the family, and later classified the then known genera according to their degree of body sclerotization, dividing them into two informal subgroups, the «loricati», with abdominal scuti, and «molles», with soft abdomens (Simon, 1890, 1893). The monophyly of these groups is, however, doubtful, as the monophyly of the whole family (Fannes \& Jocqué, 2008), but see Burger \& Michalik (2010).

Among the «molles», 13 South American species are currently listed in Oonops Templeton (see Platnick, 2009); two of them were described from Argentina: O. tucumanus Simon 1907, from Tucumán (whose type should be located in $\mathrm{Mu}$ seum National d'Histoire Naturelle, Paris), and O. nigromaculatus Mello-Leitão 1944, from Buenos Aires, whose type is deposited in Museo de La Plata. This genus, unfortunately, has been usually treated as a wastebasket group for soft- bodied oonopids with spinose forelegs. Recent studies suggest that at least the New World species currently attributed to the genus are not congeneric with the type species, $O$. pulcher Templeton. For example, a large group of these entities, containing the circum-Caribbean species without strong macrosetae on the forelegs and with spinose female pedipalps, has been transferred to the genus Heteroonops Dalmas 1916 (Platnick \& Dupérré (2009b). Apart from the 13 species described, judging by several collections under study, this group appears as very diverse, with a large number of species undescribed, that could belong to a still uncertain number of new genera.

In this contribution, we present the redescription of one of the two species previously described from Argentina: $O$. nigromaculatus. The examination of the syntypes of $O$. nigromaculatus and the comparison with newly collected material allowed us to identify the still unknown male of the species, which is described in this paper. The aim of this paper is to characterize the species describing the unknown male, redescribing the female from recently collected specimens, and provide distribution data. Although this species may not be closely related to Oonops pulcher, we postpone further taxonomic actions until an ongoing revision of the «molles» oonopids from South America is completed. 


\section{MATERIALS AND METHODS}

Specimens were deposited in the following collections: Museo de La Plata (MLP, Luis E. Pereira), Museo Argentino de Ciencias Naturales «Bernardino Rivadavia», Buenos Aires (MACN, Cristina L. Scioscia) and American Museum of Natural History, New York (AMNH, Norman I. Platnick). Female genitalia were observed in clove oil. Drawings were made with a camera lucida mounted on an Olympus BH-2 compound microscope. Photographs of the preserved specimens were taken with a digital camera Leica DFC 290 mounted on a stereomicroscope Leica M165 $\mathrm{C}$, and the focal planes were composed with Helicon Focus 4.62.2. The format of descriptions follows mostly Platnick \& Dupérré (2009a). All measurements are expressed in millimeters. We report GPS coordinates of the localities when available; otherwise, we provide approximate coordinates (denoted with «ca.») calculated with Google Earth (http://earth.google.com) from label data.

\section{SYSTEMATICS}

Family OONOPIDAE Simon 1890

Genus Oonops Templeton 1835

\section{Oonops nigromaculatus Mello-Leitão}

(Figs. 1-12)

O. nigromaculatus Mello-Leitão 1944: 323; female lectotype and female paralectotype (here designated) from Argentina: Buenos Aires: José C. Paz, Rosas Costa leg., V.1941, (deposited in Museo de La Plata, MLP 15910, PBI_OON 00015064), examined.

Additional examined material: ARGENTINA: Buenos Aires: Reserva Natural Otamendi, ca. S $34^{\circ} 13^{\prime}-\mathrm{W} 58^{\circ} 54^{\prime}$, 10.VI.1997, M. Ramírez, L. Compagnucci, C. Grismado \& F. Uehara coll., $10^{7}, 1$ immature (MACN-Ar 15370, PBI_OON 00014797); Atucha, ca. S $33^{\circ} 58^{\prime}$ - W $59^{\circ}$ 17', 27.VII.1991, M. Ramírez coll., 1 우 (MACN-Ar 15365, PBI-OON 00014801); Open Door, ca. S $34^{\circ} 19^{\prime}$ - W $58^{\circ} 59^{\prime}$, X.1982, P. Goloboff, A. Roig \& M. Ramírez coll., 1 ㅇ (MACN-Ar 15363, PBI_OON 00014802); Entre Ríos: Parque Nacional El Palmar, ca. S $31^{\circ} 55^{\prime}$ - W 58 $18^{\circ}$ ', 2223.XI.2003, C. Grismado, A. Ojanguren \& F. Labarque coll., sifting leaf litter 1 \& (MACN-Ar 16020, PBI OON 00014806); same data, pitfall, 1 을 (MACN-Ar 16021, PBI_OON 00014807); Córdoba: $1 \mathrm{~km} \mathrm{~N}$ Las Jarillas on road to Bosque Alegre from V. Carlos Paz, ca. S $31^{\circ} 35^{\prime}-\mathrm{W} 64^{\circ}$ $33^{\prime} \mathrm{W}$, rock road bank below pasture, 15.III.1988,
F. Coyle, R. Bennett \& P. Goloboff coll., 1 \& (AMNH, PBI_OON 00001859). URUGUAY: Lavalleja: Minas, Cerro Arequita, S $35^{\circ} 17^{\prime} 42^{\prime \prime}$ - W 55² 15' 58", XII.1997, M. Ramírez \& L. Compagnucci coll., $1 \sigma^{7}, 1$ 우, 2 immatures (MACN-Ar 15373, PBI_OON 00014784); Rocha: Picada de los Ciervos, Parque Nacional Santa Teresa, $15 \mathrm{~m}, \mathrm{~S} 34^{\circ} 0^{\prime} 36,3^{\prime \prime}$ - W $53^{\circ} 33^{\prime} 27,1^{\prime \prime}$, 11.XII.2005, F. Labarque, A. Ojanguren \& C. Mattoni coll. 1 오 (MACN-Ar 17993, PBI_OON 00014893).

Diagnosis. $O$. nigromaculatus is the only species among all the currently listed in Oonops in which the males have a narrow, darkened, sclerotized stripe on the anterodorsal part of the abdomen (Fig. 10). Females are distinguished by the shape and conformation of the internal genitalia (Fig. 6-9, although this feature has not been reported for most of the species of the genus).

Description of male (MACN-Ar 15370, PBI OON 14797, Fig. 10). Total length 1.69. CEPHALOTHORAX: Carapace dark red-brown, without any pattern, ovoid in dorsal view, pars cephalica strongly elevated in lateral view, anteriorly narrowed to 0.49 times its maximum width or less, with rounded posterolateral corners, surface of elevated portion of pars cephalica smooth, sides smooth, thorax without depressions, fovea absent, lateral margin straight, smooth, without denticles; non-marginal pars cephalica and thoracica setae absent, probably lost (bases remain); marginal setae dark, needle-like. Clypeus margin unmodified, curved downwards in front view, vertical in lateral view, low, ALE separated from edge of carapace by less than their radius, median projection absent; setae absent. Chilum absent. Six eyes, well developed, all subequal, ALE circular, PME and PLE oval; posterior eye row recurved from above, straight from front; ALE separated by their radius to diameter, ALEPLE separated by less than ALE radius, PME touching, PLE-PME separated by less than PME radius. Sternum as long as wide, yellow-brown, uniform, not fused to carapace, microsculpture absent, anterior margin unmodified, posterior margin not extending posteriorly of coxae IV, anterior corner unmodified, distance between coxae approximately equal, lateral margins unmodified; setae sparse, dark, needle-like, evenly scattered, originating from surface, without hair tufts. Mouthparts: Chelicerae, endites and labium yellow-brown. Chelicerae straight, anterior face unmodified; directed medially, shape normal, without prominent basal process, tip unmodified; setae dark, needle-like, evenly scattered; paturon inner margin with pairs of enlarged setae, distal region unmodified. Labium transversely elon- 

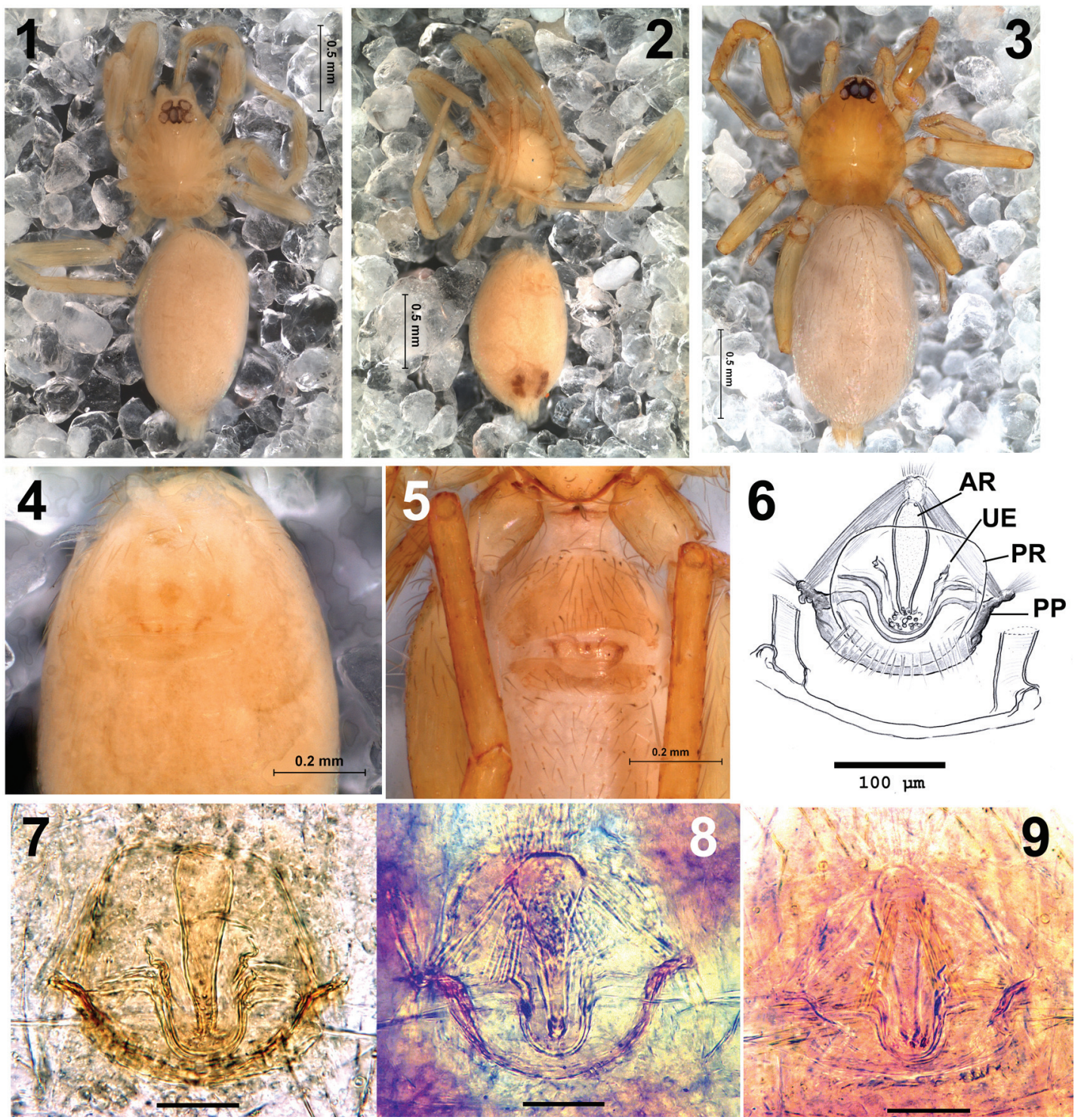

Figs. 1-9. Oonops nigromaculatus Mello-Leitão 1944, females. 1, 2, 4, 8, female lectotype; 3, 5, 6, female from Picada de los Ciervos (MACN-Ar 17993); 7, female from Cerro Arequita (MACN-Ar 15373); 9, female paralectotype. 1, 3, habitus dorsal; 2 , same, ventral; 4-5, epigastrium, ventral; 6-7, vulva, dorsal; 8-9, same, ventral. AR: anterior receptaculum, PP: posterior receptaculum, PP: posterior plate, UE: uterus externus. Scale bars: $1-3=0.5$ $\mathrm{mm} ; 4-5=0.2 \mathrm{~mm} ; 6=100 \mu \mathrm{m} ; 7-9=0.05 \mathrm{~mm}$.

gated hexagon, not fused to sternum, anterior margin indented at middle, same as sternum in sclerotization, subdistal portion with unmodified setae. Endites distally not excavated, serrula present, anterior part less sclerotized, with a lamellar lateral projection, posteromedian part unmodified, same as sternum in sclerotization. ABDOMEN: ovoid, rounded posteriorly; dorsum soft portions pale white, without color pattern, with a narrow, longitudinal, differently sclerotized stripe, reaching to the half of the dorsum.
Book lung covers large, ovoid, without setae, anterolateral edge unmodified. Posterior spiracles connected by a groove. Pedicel tube short, unmodified. Dorsal scutum absent. Epigastric scutum weakly sclerotized, not surrounding pedicel, not protruding, small lateral sclerites absent. Postepigastric scutum weakly sclerotized, yellow-brown, short, only around epigastric furrow, not fused to epigastric scutum, anterior margin unmodified, without posteriorly directed lateral apodemes. Spinneret scutum present, in- 


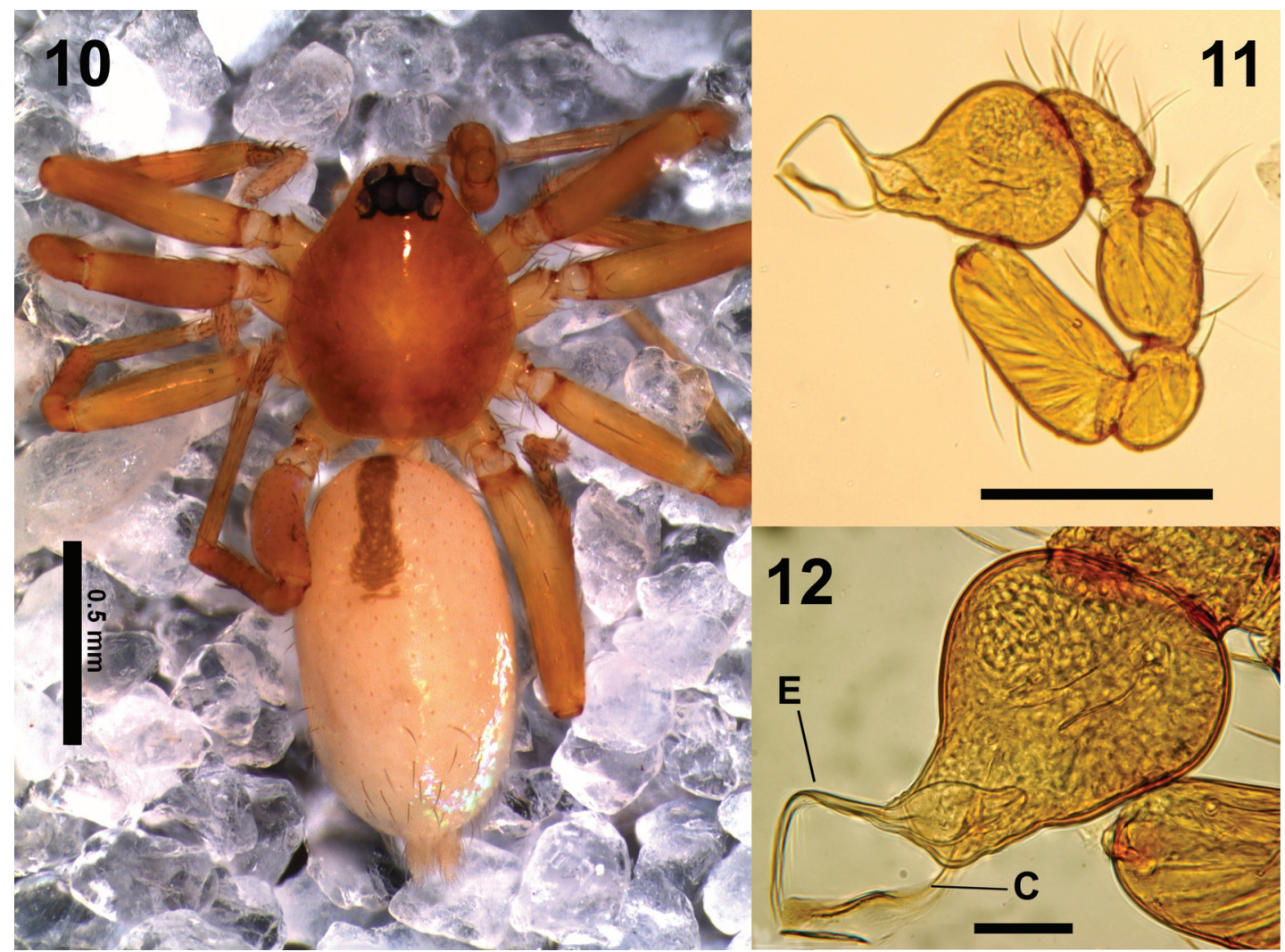

Figs. 10-12. Oonops nigromaculatus Mello-Leitão 1944, males. 10, Reserva Natural Otamendi (MACN-Ar 15370); 11-12, Cerro Arequita (MACN-Ar 15373). 10, habitus, dorsal; 11, left palp, retrolateral view, 12, same, detail of the bulb. E: embolus, C: conductor. Scale bars: $10=0.5 \mathrm{~mm} ; 11=0.2 \mathrm{~mm} ; 12=0.02 \mathrm{~mm}$.

complete ring. Dorsum setae present, dark, needle-like. Epigastric and postepigastric area setae uniform, dark, needle-like. Colulus absent. LEGS: yellow-brown, without color pattern; femur IV not thickened, same size as femora I-III, patella plus tibia I near as long as carapace. Leg spination (only surfaces bearing spines listed, all spines longer than segment width): femora: I d1$0-0$, pv0-0-1-1-0; II d1-0-0, pv0-0-0-1-0; III, IV d1$0-0$; tibiae: I v2-2-2-2-0; II v2-2-2-2-0; III v0-0-1, p1-1; IV v1-0-1, p1-1, r1-0-0; metatarsi: I v2-2-2, II v2-2-2, III v0-0-2, IV p1-0-1; v1-0-0. Tarsi I to IV without inferior claw. Trichobothria not examined.

GENITALIA: Epigastric region with sperm pore not visible; furrow without setae. Palp normal size, not strongly sclerotized, right and left palps symmetrical, proximal segments yellowbrown; embolus dark, curved; trochanter normal size, unmodified; femur normal size, two or more times as long as trochanter, without posteriorly rounded lateral dilation, attaching to patella basally; patella shorter than femur, not enlarged, cymbium yellow-brown, ovoid in dorsal view, not fused with bulb, not extending beyond distal tip of bulb; bulb pale orange, $+/-1.5$ times as long as cymbium, stout, tapering apically, distal part transversally truncated in dorsal view, with a anteriorly directed «conductor» partially traslucent, with undulated margin, touching distally the embolus (as in Figs. 11-12).

Female (MACN-Ar 17993, PBI_OON 14893, Figs. 3, 5-6). Total length 1.83. As in male except as noted. CEPHALOTHORAX: Carapace yellowbrown; non-marginal pars cephalica setae dark, needle-like, present, scattered; non-marginal pars thoracica setae dark, needle-like. Clypeus setae present, dark, needle-like. Eyes PLE circular. Labium broad, transversely elongated hexagon. Palp claw absent; tarsus unmodified. ABDOMEN: dorsum soft portions without the dorsal sclerotized stripe of the males. Colulus represented only by setae. LEGS: pale orange. Leg spination (only surfaces bearing spines listed, all spines longer than segment width): femora: I d1-0-0, pv0-0-1-1-0; II d1-0-0, pv0-0-0-1-0; III, IV d1-0-0; tibiae: I v2-2-2-2-0, II v2-2-2-2-0, III v00-1, r0-0-1, p1-1; IV d0-1-0; p1-0-1; v1-0-2; metatarsi: I, v2-2-2, II v2-2-2; III v0-0-2; r0-1-0, p1-1; IV d0-1-0; p1-0-1; v1-0-2; r1-0-0. 
GENITALIA (Figs. 4-9): The genital opening connects to the uterus externus, from which two receptacula emerges: one anterior and other posterior (larger and spherical), as a typical pattern known in Dysderoidea (Forster \& Platnick 1985, Grismado 2008). The long anterior receptacle have accesory glands and several pairs of muscles attached: one anteroventrally, one posteroventrally (both presumably to the ventral cuticle) and one pair to the lateral projections of a sclerotized posterior plate that lies in the posteroventral wall of the posterior receptaculum. The anterior part of the posterior plate has an U or V-shaped margin that corresponds with the shape of the anterior ridge of the opening of the uterus externus, which forms a kind of transverse u-shaped locking mechanism. The basal part of the anterior receptacle is darkened, visible ventrally by transparence, surrounded posterolaterally by the U-shaped sclerotized elements. Dorsal view: anterior receptacle long, gradually widened apically, with rounded end and accessory glands restricted to its base. The distal section of the uterus externus has folded edges.

Remarks. The syntypes are in poor condition (Figs. 1, 2), but the genitalia are still observable and very similar to those of the newly collected females here considered conspecific (Figs. 4, 8-9). The female from Córdoba has a remarkably widened distal part of the anterior receptacle, but this variation is presumed as intraspecific, given that this feature is also observed in the specimen here designated as lectotype. The dark semicircular spots at the sides of the spinnerets (very conspicuous in the lectotype, and that gave the specific name, Fig. 2) are not evident in all the specimens. In the original description, Mello-Leitão mentioned three spines on the anterior femora, but the syntypes and the newly collected specimens have only two prolateral ventral spines on the femur I, and only one on the femur II.

Distribution. Known only from Argentina (Buenos Aires, Entre Ríos and Córdoba) and Uruguay (Rocha and Lavalleja).

Natural history. Some specimens were collected in Parque Nacional El Palmar with pitfall traps in a grassland, and sifting leaf litter in a forest close to a small river.

\section{ACKNOWLEDGEMENTS}

We wish to thank the institutions and curators listed in the «Introduction» for loaning the relevant specimens under their care; to Martín J. Ramírez, Cristina L. Scioscia, Gustavo Hormiga, and the editors for their critical comments on the manuscript. C. G. was supported by a grant of the U. S. National Science Foundation (0613754) for a Planetary Biodiversity Inventory of the spider family Oonopidae to $\mathrm{N}$. Platnick, C. Griswold, R. Gillespie, P. Sierwald and G. Hormiga.

\section{BIBLIOGRAPHY}

Burger, M., \& P. Michalik. (2010). The male genital system of goblin spiders: evidence for a monophyly of Oonopidae (Arachnida, Araneae). Am. Mus. Novit. 3675: 1-13.

Fannes, W. \& R. Jocqué. 2008. Ultrastructure of Antoonops, a new, ant-mimicking genus of Afrotropical Oonopidae (Araneae) with complex internal genitalia. Am. Mus. Novit. (3614): 1-30.

Forster, R.R. \& N.I. Platnick. 1985. A review of the austral spider family Orsolobidae (Arachnida, Araneae), with notes on the superfamily Dysderoidea. Bull. Am. Mus. nat. Hist. (181): 1230.

Grismado, C.J. 2008. A taxonomic revision of the spider genus Ariadna Audouin, 1826 in Argentina and Chile, with the description of five new species (Arachnida, Araneae, Segestriidae). Zoosystema (30): 333-360.

Jocqué, R. \& A.S. Dippenaar-Schoeman. 2006. Spider Families of the World. Musée Royal de l'Afrique Central, Tervuren, $336 \mathrm{pp}$.

Platnick, N.I. 2009. The World Spider Catalog, Version 9.5. American Museum of Natural History, online at: http://research.amnh.org/entomology/spiders/ catalog/index.html

Platnick, N.I. \& N. Dupérré. 2009a. The goblin spider genera Opopaea and Epectris (Araneae, Oonopidae) in the New World. Am. Mus. Novit. 3649: 1-43.

2009b. The goblin spider genus Heteroonops (Araneae, Oonopidae) with notes on Oonops. Am. Mus. Novit. 3672: 1-72.

Simon, E. 1890. Etudes arachnologiques. 22e Mémoire. XXXIV. Etude sur les arachnides de l'Yemen. Ann. Soc. Entom. de France (6)10: 77-124.

- 1893. Histoire naturelle des araignées (1): 257-488. Paris: Roret. 